\title{
The Employment of Indian Auxiliaries in the American War
}

\begin{abstract}
A $\mathrm{T}$ the outbreak of hostilities between Great Britain and the A American colonies in $\mathbf{1 7 7 5}$, it was evident to all thoughtfol persons on both sides of the Atlantic, that uniess the contest should be speedily decided, the natives would be employed as anxliaries upon the one side or upon the other, perhaps upon both. In all the previous wars on this continent between the French and the English, Indians had thus been made use of. Custom had familiarised colonists and soldiers with their co-operation in military movements, and experience had taught the improbability of being able to carry on important campaigns which should trespass upon Indian territory, without securing the consent of the natives by alliance, or arousing their hostility by invasion. The Indian population at that time, east of the Mississippi and within the borders of the territory which now constitutes the United States, was not far irom 150,000 persons: The total number of warriors who could be brought into the field was about 35,000. Two-thirds of these gun-men, as they were called by some writers, lived so far from the probable scene of action that they were not likely to be drawn into the contest. What position the other third would take was a matter of great interest to the colonies. The policy which was to govern the 2,000 warriors of the Six Nations was of especial importance. This importance arose from the supremacy of this confederacy among the Indians living within the borders of the colonies; from the proximity of their homes to settlements in New York and Pennsylvania, and from the fact that if Great Britain should retain control of Canads, it was probable that movements of troops would take place within the limits of what was recognised as their country.

Of scarcely less importance was the question what position world be assumed by the tribes which inhabited the region about Detroit and the central portion of Ohio. The relations of the 8,000 warriors of this confederacy to the possible war were inferior in importance to the relations of the Six Nations to the same question,
\end{abstract}


because the tribes of the Miami confederacy, or many of them, were conquered tribes and dependent upon the Sir Nations, and because military movements by the English in that part of the country could not readily be conducted without alliance with the Six Nations. On the other hand, if that confederacy shonld take the side of Great Britain, then access to the post at Detroit would remain open by way of the St. Lawrence and the lakes; the post could easily be maintained, and through the aid of Indian auxiliaries the colonies could be threatened in the rear.

The warriors of the Choctaws, Creeks, Cherokees, and Catambas, who came in contact with the colonists along the borders of North and South Carolina and Georgia, numbered 9,500 men. ${ }^{1}$ What they would do was of importance; but though their numbers were greater than those of either of the confederacies already mentioned, the geographical situation of their homes deprived them of political power.

I think it may fairly be said that the natural gravitation of all the Indian tribes was towards Great Britain, and not towards the colonies. The British government, as represented by the superintendents of Indian affairs, had been more just in dealing with the natives than had the colonists. Indeed, the main daties of the superintendents had been to protect the various tribes from acts of settlers. After the failure of Pontiac's conspiracy, the boundary line had been formally adjusted between the Indians of the northern department and representatives of the British government. It was agreed that the whites should have possession of the conntry east and sonth of a line drawn from Oneida lake to the junction of the two branches of the Susquehanna; thence up the west branch of that river and over the mountains to the Alleghany river; thence down that river and the Ohio to the month of the Tennessee river. No consideration was taken in this agreement of the rights of the southern Indians to their honting grounds in Tennessee and Kentacky.

Sir William Johnson was at that time in charge of the northern department of Indian affairs. He had built for himself a comfort. able mansion in the Mohawk valley, and he lived in the midst of the tribes whom he laboured to protect. They listened to his counsel. They believed that he was their friend, and their affection for him extended to the varions members of his family. Within the reach of his personal supervision the Indians were reasonably free from many of the trials to which they were elsewhere sabjected. His department ran from the ralley of the Mohawk to the banks of the Mississippi, and from the Ohio river to the shores of Lake Superior. $\mathrm{He}$ conld hold in restraint the Germans and the Dutch in the neighbourhood of his home, but

- Georgia Hist Coll. Sarannah, 1873, iii. 169. 
his deputy had little control over the frontier population which was pressing westward into the valley of the Ohio. Between Virginis and Pennsylvania a dispute was in progress as to which colony had jurisdiction over a portion of this valley, a dispute which carried with it the consequence that for many years the settlers in western Pennsylvania and in north-western Virginia had no knowledge as to which colony was entitled to their allegiance, and no way of finding out what laws, if any, governed the localities which they had selected for their homes. Land companies and individuals were at that time eager to secure titles in the valley of the Ohio. Washington was anxious to get for his soldiers the land bounties offered by Dinwiddie during the French war. He was himself entitled to some land in his own right, and to more through rights of others which he had purchased. He employed an agent whom he urged to secure still more, saying to him, 'My plan is to secure a good deal of land.' 2

Notwithstanding the fact that the Fort Stanwix treaty lodged the title to the lands south of the Ohio in Great Britain, the Indians in that region told Washington, when he was there in 1770 , that they looked upon the settlements of the whites with a jealous eje, and that they must be compensated for their rights if the settlers were to remain, without regard to the cession by the Six Nations. It was not alone movements of emigrants upon lands to which there was by treaty a certain foundation of right that alarmed the Indians of that vicinity. The fascination of danger in border life and its freedom from restraint attracted to the frontier men who cared nothing for treaties and whose object was to get beyond the reach of law. Many of these reckless characters, taking their lives in their hands, penetrated the country reserved by the Indians for their hunting grounds, and took up claims there which they called, in the vernacular of the frontier, 'tomahawk rights,' and which they hoped might at some futare time have value. The danger from the presence of these people in Indian territory became so conspicuous in 1772 , that General Gage issued a proclamation ordering them all to leave that region and to take refuge in some of the colonies. The government, however, was porerless to enforce sach a proclamation. It was, in fact, dependent upon these very men in times of Indian outbreak for its defence, and there were some among them who fully appreciated their own value in the military situstion. The power of the superintendent to preserve peace was still further strained by claims which were occasionally set up by whites, of titles to land by purchase from the Indians. Against these transactions laws had been passed in most if not in all of the colonies. In addition, the parchase of land from the natives by private persons had been forbidden by royal procla-

\footnotetext{
I Sparks's Tashington, ii. 348.
} 
mation. Such purchases were nevertheless a source of danger which accasionally obtruded itself.

The natives had a knowledge of the ownership of land, and while they bnew nothing concerning technical rales or methods for passing title as between themselves, there were circumstances ander which they understood that the relinquishment of their rights had been accomplished. The ownership of their homes and hunting places was supposed to be rested in the whole tribe. No assignment or deed woold be voluntarily assented to which had not been carefully considered by all who were interested. In many cases the women as well as the men were entitled to be heard before the transaction conld be considered as complete. It was an easy matter for designing whites to secure from Indians who had no right whatever to make them deeds which even though repudiated by the true owners of the land were powerful as sources of annoyance and irritation when held as threats over the tribes who, it was claimed, had executed them. There were instances on record where the Indians acknowledged that they had executed certain instraments, but claimed that the signers of the deeds had first been completely intoxicated. In other cases they claimed that the territory conveyed by the deed far exceeded what they had intended to grant. To protect the natives against transactions of this sort Sir William Johnson had pat forth every exertion. Furthermore he had always recognised the danger to which the natives were exposed from the lawlessness of the trespassers on Indian territory. By these means his influence among them had been powerful enough, notwithstanding the danger of the situation, to preserve peace along the border from the time of Pontiac's conspiracy down to the outbreak at Point Pleasant, Virginia, in 1774.

The foregoing brief recrpitalation of the state of affairs along the border daring the years just before the revolution sufficiently illustrates why the Indians naturally looked upon the colonists as more aggressive than the British government, and also shows the foundation for Sir William Johnson's influence with the nstives. There wes still another circurnstance which increased the influence and riveted the power of the superintendent. The government was accustomed to make an annual distribution of presents to the natives, and the superintendent was the officer through whom these presents were distributed. The Indians had come to rely upon this annual source of supply, and it was of importance to them that it should not be interrupted. The colonies could not expect to offset this source of influence except by pursuing the same course.

The death of Sir William Johnson, in 1774, relieved that re. markable man from the struggle to which he would have been subjected from his affection for the home of his adoption and his loyalty to the crown. The office of superintendent devolved apon 
Guy Johnson, his son-in-law. The success of the latter in restraining the Six Nations from outbreak at that time showed that he had inherited the good will of the Indians, and that the office of superintendent wos still powerful for good or evil. Guy Johnson was loud in professions of friendship for his neighbours, open and above-board in arowals of loyalty to the crown, and prompt in action against those whom he considered rebels, when instracted thereto by General Gage.

In the south, John Stuart had charge of the Indian department. He, also, professed friendly feelings towards the colonists, and was evidently unwilling to make ase of the Indians against them. Yet when he received orders from head-quarters to spare no efforts to harass the colonists, he yielded ready obedience.

In Grest Britain there was andoubtedly a strong feeling of abhorrence aroused in the public mind at the ides of making use of Indians in a war against a people who were still regarded as fellowsubjects. This feeling was made the most of in parliament by the opposition, when at a later period it was understood that the government was folly committed to the step.

In America it may well be doubted whether this feeling of abhorrence was so common. The danger to be apprehended from the natives was fully appreciated; but it was also understood that unless Cansda could be secured, the Indians would have a hand in the war. Nevertheless, it is evident from the language ased in the address to the people of Ireland and in the declaration of independence, that the Americans felt that the publication of the charge that the king was making ase of savages in his efforts to subdue his revolted subjects, would appesl to the prejudices and excite the sympathies of those who should read the documents.

From the outset each side apparently endesvoured to cast upon the other the responsibility of having first made use of Indians as auxiliaries in the struggle. In Jone 1775 the continental congress declared that Governor Carleton was making preparations in Canads to invade the colonies, and was instigating the Indian nations to take up the hatchet against them. The same month that congress made this assertion, General Gage wrote to the earl of Dartmonth that the acts of the rebels would justify General Carleton in raising bodies of Canadians and Indians. "We need not be tender of calling on the savages,' he added, 'as the rebels here have shown us the example by bringing as many Indians down against us bere as they could collect.' 3 In the instructions which Gage, just before he left Boston, issued to Stuart, this statement was repeated with additions as follows: "They have brought down all the savages they could against as here, who, with their riflemen, are continually firing upon oor advanced sentries.' 4

3 dm. Archives, th series, ii 968.

Bancroft, 7iii. 88. 
American writers of history have done full justice to the memory of Carleton. It is known through their pages that he was averse from the use of savages in aggressive movements. He was anxious to conciliate them, and willing to use them for defensive parposes, but would not consent thet those who had been employed under his immediate supervision should be used outside the limits of his province. The same writers have not, however, done equal justice to General Gage. Bancroft, commenting on the first of the letters to which I have referred, says: ${ }^{3}-$

'We need not be tender of calling apon the savages,' were his words to Dartmouth ; some of the Indians, domiciled in Massachusetts, having strolled to the American camp to gratify curionity or extort presents, he pretended to excuse the proposal which he had long meditated, by falsely asserting that the Americans ' had brought down as many Indians as they conld collect.'

Was this assertion of Gage's false? If not, then much of the foeling which has been directed againgt Gage is ill-founded, and the orders issued by Dartmouth in the fall of the same year, to enlist Indians because the Americans were doing the same thing, are not without the justification upon which they were based. Gage's statement has always been classed with Lord Dunmore's proposal to raise in May a force of Indians, negroes and others, with which he hoped to be able, if not to subdue rebellion, at least to sustain government. If Gage's statement was true, it makes the brutality of Dunmore's proposition all the more conspicuous in its solitary disregard of public estimate of methods.

The answer to this question is to be found in the 'Proceedings of the Provincial Congress of Massachusetts Bay,' from which it appears that even before the battle of Lexington some of the Stockbridge Indians had been enlisted as minute-men. This fact is stated in the preamble to a resolution reported by the committee on the state of the province, on 1 April $1775 . .^{\circ}$ In parsuance of the recommendstions of this committoe, it was ordered that a letter to the Rev. Mr. Kirkland and an address to the Mohawk tribes be drafted. Kirkland was a missionary who was familiar with the Indian dialects in use in the Mohawk velley. He had spent several years in that vicinity, and had acquired great influence over the Oneidas. The letter which was prepared in pursuance of this order requests Mr. Kirkland to use his influence with the Six Nations 'to join with us in the defence of our rights,' bat if he could not 'prevail with them to take an active part in this glorious cause,' he was 'at least to engage them to stand neuter.' The address to the Mohawks calls upon them to "whet their hatchet and

- Bencroft, vii. 392.

- Am. Arehives, th series, p. 1347. Joumals of ach Provincial Congras of Mate. Boston, 1888, p. 114. 
be prepared with us to defend our liberties and lives.' Through the same channel of information, we learn that fondness for liquor brought these enlisted Indians very soom into trouble. Whereupon serenteen of them petitioned the provincial congress that liquor might be kept out of their way. This petition was duly granted and measures taken to carry it into effect.

It will be remembered that Gage in his letter to Strart, which has been already alluded to, spoke not only of the presence of Indians in the American camp, but also complained that they and the riflemen shot his sentries. From several sources we learn that this was true. Frothingham, in his 'Siege of Boston,' speaks of the Stockbridge Indians as follows: 'A company of minute-men before the 19th of April had been embodied among the Stockbridge tribe of Indians, and this company repaired to camp. On Jane 21, two of the Indians, probably of this company, killed four of the regulars with their bows and arrows, and plundered them.' The same author mentions the following incidents which happened during the siege: 'June 25: This day the Indians killed more of the British guard. Jane 26: Two Indians went down near Bunker Hill and killed a sentry.' $\mathrm{He}$ also gives the following: 'A letter of July 9 says : "Yesterday afternoon some barges were sounding the river of Cambridge (Charles) near its mouth, but were soon obliged to row off by our Indians (fifty in number), who are encamped near that place." " Lieut. William Carter, of the 40th regiment of foot, under date of $7 \mathrm{July} 1775$ wrote: "Never had the British army so ungenerous an enemy to oppose; they send their riflemen (five or six at a time), who concesl themselves behind trees \&c. till an opportunity presents itself of taking a shot at onr advanced sentries, which done they immediately retreat. What an infamous method of carrying on a war!' 10 The Boston Gazette of 7 Aug. 1775 says: 'Parties of riflemen together with some Indians are constantly harassing the enemy's adranced guards, and say they have killed several of the regulars within a day or two past.' The issue of 14 Aug. says : 'We hear that last Thursday afternoon a number of riflemen hilled two or three of the regalars as they were relieving the sentries at Charlestown.

Candour compels the admission that Gage's statement that the rebels were bringing dorn all the Indians that they conld, and that

Th. Archives, 4th sories, p. 1850. Jowrnals of ach Provincial Congress of Hass. p. 118.

- These incidents are taken by Frothinghem trom the dinry of Jahn Rottel, a rell-known resident of Cherlestown. Through the conrtesy of Thomes $G$. Frothingham, I have had an opportanity to exnmine the entire diary and verity the quotations.

- Siege of Boston, pp. 212-13.

10 A Genurine Detail of the Soveral Engagemonts, ten with an Lcoorent of the Blockade of Boston, dtc., in a Series of Lettors to a Friond, by William Certar, late a lieutenent of the 40th Regiment of Font. Iondon. 1784. 
they and the riflemen were shooting his sentries, was not mere gasconade. His indignation was founded on facts. In asserting that the Americans were bringing down all the Indians that they could, he probably stated more than he knew, but even in that assertion he seems to have been within the lines of trath. We have already seen that efforts were put forth by the provincial congress in April to secure if possible the services of the Mohswks, or at least to keep them neutral. Further efforts were apparently made about the same time to obtain more recruits from the Stockbridge Indians. This is shown by a letter dated April 11, from their chief sachem to the president of the provincial congress, in answer to a communication received by him. In this letter he offers to visit the Six Nations and find out how they stand. 'If I find that they are against you,' he says, 'I will try and turn their minds.' 'One thing I ask of you, if you send for me to fight, that you will let me fight in my own Indian way.' " To the eastward, in Nora Scotia, there was a body of Indians from whom recruits might be drawn. To them a communication was sent by the provincial congress of Massachusetts Bay, in which they were addressed as 'friends and good brothers,' and told that 'the Indians at Stockbridge all join with as and some of their men have enlisted as soldiers.' 12 Captain Lane was sent down among them, and they were told that he would show his orders for raising one company of their men, who were, as the committee phrased it, 'to join with us in the war with your and our enemies.' Nothing of importance came of this attempt. Captain Lane made his trip, and in June returned, bringing with him one chief and three young men.

During the period covered by the foregoing events provincial officers had made similar propositions to the Indians. Some of these proposals were perhsps unsuthorised, but some were apparently made by authority. On 24 May Ethan Allen addressed a letter to several tribes of Canadian Indians, asking their warriors to join with his warriors, ' like brothers, and ambush the regalsrs.' This proceeding he reported to the general assembly of Connecticut two days afterward. ${ }^{13}$ On 2 June, Allen proposed to the provincial congress of New York an invasion of Canada, urging as one reason therefor that there would be 'this unspeakable advantage, that instead of turning the Canadians and Indians against us, as is wrongly suggested by many, it would unsoidably attach and connect them to our interest.' From Newbury Colonel Bayley on 23 June addressed the northern Indians as follows: 'If you have a mind to join us, I will go with any number you shall bring to our army, and you shall each have a good coat and blanket \&c.

\footnotetext{
"Am. Archioss, th Series, ii. 816, where it is stylod ' Speoch delivered by Captain Solomon Uhhamanawennmat,' de.

12 Ibid. 610, 611 .

Is Ibid 714
} 
and forty shillings per month, be the time longer or shorter.' "4 In September, Annold started on his march through the wilderness for Quebec. At Sartigan the troops were joined by a number of Indians, to whom Arnold offered 'one Portuguese per month, two dollars bounty, their provisions and the liberty to choose their own officers.' Ahout fifty of them took their canoes and proceeded with the invading column. ${ }^{15}$

The results of these efforts of the provincial congress of Massachusetts Bay and of the officers in the field to secure recruits from the Indians, were insignificant. So few were the numbers of the natives in the American force that their presence there has been ignored and even denied by historians. The roice of the continental congress as heard in the address to the people of Ireland and in the declaration of independence has been accepted as anthority for the opinions of the people of the colonies; and it has in many instances been assumed that the acts of the people were consistent with the opinions thus attributed to them. To Gage, penned in upon the peninsula of Boston, it mattered little what position the continental congress either had taken or would take upon the subject. Massachusetts Bay was the province where rebellion had first hoisted its standard, and Massachusetts Bay had enlisted Indians whose presence had been made manifest to him by their killing his sentries. As events rolled on, the army began to assume a national aspect, and Mrassachusetts lost her pre-eminence in military affairs. The attempt of that province to secure Indian recraits was buried from observation beneath its practical failure. It is not strange that the fow Indians in the American army were lost sight of: and that their presence in the field in the northern department during the ensuing campaigns is only occasionally alluded to. The more conservative position of the continental congress has com. pletely overshsdowed the previous acts of Massachusetts Bay in the eye of historians.

The journals and the secret journals of the continental congress were published many years ago. A chronological review of the legislation bearing upon the employment of Indians, which is recorded in those journals, will better enable as to estimate the true extent of the conservatism of that body on the subject.

In June 1775, congress asserted that Carleton was 'instigating the Indian nations to take up the hatchet against the colonies.' ${ }^{16}$

" $\Delta m$. Archives, 4th Series, ii. 1070.

is The Journal of Isace Senter, publishod by the Hirtorical Society of Pennsylvanie, Pbiledelphis, 1846, p. 24.

11 In attempting to measure the weight which ought to heve been given to rumours of this sort, we must not overlook the fuct that the knoviledge which we heve of tice sitantion of affeirs is much more comprehensive than thet which prevailed among those who were directly in contect with erents. Suspicion had from the outset been directod against Carieton. It was founded not so mach upon personal distrust as 
As a matter of fact, Guy Johnson in the latter part of that month did hold a conference at Oswego, at which he secured promises of co-operation from a portion of the Six Nations, and in Jaly he held another conference at Wontreal, at which similar promises were obtained from the Indians who were present. Of these conferences, congress at that time knew nothing. The Americans who were then in correspondence with our emissaries in Canada were full of hope that the Canadian Indians would prove friendly to the American cause. It was not perhaps fully appreciated at the time, but it is known to us to-day from complaints in Guy Johnson's letters, that Carleton, the governor of Canada, was opposed to raising Indians in Canada for use outside that province. The colonies had not much cause to fear invasion from a force of Indians believed to be friendly, to be raised by a governor who was opposed to their being used outside the limits of his province. It is not improbable that the passage of a resolution to this effect was secured by those who favoured employing Indians as soldiers, for the purpose of consolidating opinions within the continental congress. Among the members there were men who were appointed from communities which would be exposed in case of an Indian uprising. Such men were naturally reluctant to commit themselves on the subject. There were undoubtedly some members of the congress who would have refused to initiate the employment of Indians in the army so long as hopes existed of keeping them out of the contest, bat who would not have hesitated to avail themselves of their services if they saw clearly that the natives would otherwise be employed by the English. By recording this positive expression of opinion in congress the foundation was laid for the decisive steps afterwards taken. That the danger from this source was exaggerated is plain. It may well be doubted whether those who were in correspondence with the

upon the comprehensivo powers given him in his commission to levy troops without limitation as to their character, and to sabdao rebellion oren ontside the limite of his province. At a period of such excitement, it was not possibie thet men should stop to ant how such langasge came to be ased. It was assumed that the potrers conferred upon him were bestorred on account of the impending crisis, and every conference that he held with Indiang was wetohed with suopicious eje. There was, however, no especial reason for suspecting Carloton, nor was the lenguage used in the commission carese in itself for suspecting the intentions of the home government. Eleven years before Curleton was appointed, the seme language tras inserted in the commission of his predocessor. Hed Murray remained at Quebec, no especiel argament conld heve been tounded on the language of a commission issued in 1768 . Similar languge $\mathrm{mas}$ mede use of in the commission of Sir Denvers Osborn in 1754, when he was eppointed governor of Ner Fork. Indeed, the objectionsble phrases seem to heve been mere forms of words, which were copied trom some of the colonial eharters. They are to be found in the ebarter of Maryland and in the first and second charters of Caroline.

It is eagy to conoeive what powron argaments could have been based upon the langarge of the commission. Hen could not stop to hant up the precedents apon which the commistion was founded. The powers conferred by it were supposed to heve been created for the emergency, and Carleton was believed to be about to meke use of them. 
American emissaries in Canada believed in it. Public opinion was at that time often inflnenced by publications prepared for the purpose. Of the trath of some of them, the authors, according to Judge Marshall, were not always mindful. ${ }^{17}$ It would not be surprising if the continental congress was swayed in this instance by means of this sort.

The next step taken by congress which bears apon the subject was, on 30 June, to instruct the committee on Indian affairs ' to prepare proper talks to the several tribes of Indians for engaging the continuance of their friendship to us, and neutrality in our present unhappy dispate with Great Britsin.' On 1 July it was resolved, 'that in case any agent of the ministry shall induce any Indian tribes, or any of them, to commit actual hostilities against these colonies, or to enter into an offensive alliance with the British troops, thereupon the colonies ought to arail themselves of an alliance with such Indian nations as will enter into the same, to oppose such British troops and their allies.' On 6 July the statement that Carleton was 'instigating the Indians to fall upon us 'was repeated. If Carleton had mot with any success in these efforts, the contingency had already occurred which made it the duty of the colonies to avail themselves of an alliance with such Indian nstions as would enter into the same. That congress had no knowledge of any saccess on Carleton's part may be inferred from the action taken when the Indian departments were formed in the same month. At that time, notwithstanding the resolution of the first, the commissioners were authorised to treat witb the Indians for the preservation of peace and friendship. A formal address was made at the same time to the Six Nations wrging them to keep the peace, and the commissioners of the northern department were recommended to employ the services of Mr. Kirkland in this behalf.

Congress had apparently resisted the pressure brought to bear upon the members in the form of rumours from Cansda. All that they were prepared to do was to put forth an earnest effort to retain the Six Nations neatral. Meantime Washington had been appointed to the command of the army. His instructions were, 'not to disband any of the men you find raised until further directions from congress.' 18 By the terms of these instructions he was compelled to retain the Stockbridge Indians, although it is probable that but fer members of the congress were aware of that fact. The camp at Cambridge was visited during the fall of 1775 by representatives of the Canadian tribes, and from them Washington received assurances of the friendly disposition of those Indians. On 4 Aug. he reported

17 Seeletter of Maraball in Miner's Wyoming, p. 257.

to Secret Journals of the Acts and Procedings of Congress, Boston, 1821, i 17. The chronological revier of the Acts of Congress can be readily verified in the Journals and the Secret Joumals of Congress. 
to congress that he had received assurances from a Caghnawaga chief, 'that if an expedition against Canada was meditated, the Indians in that quarter would give all their assistance.' ${ }^{19}$ On 21 Sept. he reported that, 'encouraged by the repeated declarations of Canodians and Indians, and arged by their requests,' to he had despatched the Arnold expedition. Montgomery was already in Canada, and even before Washington wrote this letter the American adranced guard had been attacked near St. John's by a band of Mohawks. It is a singular fact that this act, which was probably a result of one of Gay Johnson's conferences, does not appear to have had any weight in forming public opinion. Montgomery was joined by some Canadians. Carleton wrote that many Indians had gone over to him, but Montgomery himself said, 'The Cagbnawagas have desired a handred men from us. I have complied with their request, and am glad to find that they put so much confidence in us and are so much afraid of Mr. Carleton.'

The next step taken by congress was on 2 Dec., when it was resolved that the Indians of the St. Francis, Penobscot, Stockbridge, and St. John's, and other tribes may be called on in case of real necessity. This was apparently a concession to the party which was urging the employment of Indians. Practically it amounted to nothing. From Cambridge, Washington on 24 Dec. Wrote to Schnyler : 'The proofs you have of the ministry's intention to engage the savages against as are incontrovertible. We have other confirmations of it, by several despatches from John Stuart, the superintendent for the southern district, which lackily fell into my hands.' "t Two things will be noticed in this letter: 1st. That Washington lays no stress on the information which had been current so long, and which had appeared sofficient for congress to assert twice that Carleton w8s stirring up the Indians. 2nd. That he makes nn allusion to the positive proof which Montgomery had receired that some of the Indians were already in arms against the colonies. I bnow of no explanation for this which is founded in contemporaneous records, but it seems to me improbable that Schuyler would have paraded proofs gathered from Montreal, and that Washington would have dwelt upon intercepted despatches from the sonth, if it had been known at that time that the Indians who attacked Montgomery were Mohawks. The collision was probably regarded as an encounter with some band of Canadian Indians who were not embraced within the friendly influences of the Caghnawagas, and no especial significance was attached to it. From what Washington had already said to congress, it may be inferred that even before the incontrovertible proofs referred to were submitted to him he was not averse to the use of Indians as auxiliaries. On 27 Jan. 1776 he wrote to General Schuyler that he considered the

$$
\text { "Sparks's Washingtom, iii. 55. I Tbid. } 102 \text { I Ibid. } 210 .
$$


important period had arrived 'when the Canadians, and consequently their Indians, must take a side.' As to the Caghnswagas, he said : 'I am sensible that if they do not desire to be idle, they will be for or against us. I am sensible, also, that no artifices will be left unessayed to engage them against us.' $n$ Whether be communicated these views to congress at that time does not appear, but on 8 March congress resolved that 'Indians be not employed as soldiers in the armies of the united colonies before the tribes to which they belong ahall in a nationsl conncil, held in a customary manner, have consented thereto, nor then without erpress approbation of congress.'

On 19 April 1776, Washington wrote an urgent letter to the president of cangress, in which he expressed himself concerning the employment of Indians." 'In my opinion,' he said, "it will be impossible to keep them in a state of neutrality; they must, and no doubt will, take an active part either for or against us. I sabmit to congress, whether it will not be better immediately to engage them on our side.' In May, Washington was summoned to Philadelphis for consultation concerning military matters. He arrived there on the 27th, and the next day after his arrival congress resolved ' that it is highly expedient to engage the Indians in the service of the united colonies.' The suggestion has been made that this vote was brought about in congress by the reception of news of the slaughter of prisoners by the Indians, which took place after the affair of the Cedars in Canada. This, however, was impossible. Washington did not receive news of this event antil 9 June, in New York. His letter of 19 April, aided perhaps by his presence in Philadelphia, may have influeuced the decision of congress.

On 3 June anthority was conferred upon General Washington to employ in Canada a number of Indians not axcoeding two thousend, and on the 6th of the same month instructions were given to the standing committee on Indian affairs to devise ways and means for carrying into effect the resolution of the 3rd. On 14 June the commissioners of the northern department were instructed to ' engage the Bir Nations in our interest on the best terms that can be procured.' On the 17th the restrictions in the resolntion of the 3rd, which limited to Cansds the use of the Indians to be raised, were removed, and the general was permitted to employ them in any place where he should judge they would be most useful. He was further authorised ' to offer a reward of one hundred dollars for every commissioned officer, and thirty dollars for every private eoldier, of the hing's troops, that they should take prisoners in the Indian conntry or on the frontier of these colonies.' From time to time thereafter during the war resolutions were passed by congress bearing upon the subject, and consistent with the position

- Bparts's Washingtom iii 261-8.

- Tb. p 864 . 
which congress had finally assumed. It is not important to recspitolate these in detail, bat one of them is entitled to special notice. In 1779 it was resolved that twelve blank commissions be furnished the commissioners of the northern department for the appointment of as many Indians, the name and the rank in each commission to be filled at the discretion of the commisaioners.

The struggle of opinions in congress hod culminated, a few days before news of the battle at the Cedars reached Philadelphis, with the passage of the resolution of 25 May. The several resolutions passed in June were probably caused by the indignation aronsed by the alanghter of prisoners after the battle. The next expression of opinion in congress on the ase of Indians as awriliaries is to be found in the declaration of independence, in which the king is arraigned because ' he has endeavoured to bring on the inhabitants of our fronticrs the merciless Indian serages whose known rale of warfare is an undistinguished destraction of all ages, seres, and conditions.' Four dsys after the promulgation of thst document, Washington was authorised to call forth and engage the Indians of the St. John's, Nora Scotia, and Penobscot tribes. On the 28th of the same month the address to the people of Ireland was agreed to. In this it is asserted that 'the wild and barbarous savages of the wilderness have been solicited by gifts to take up the hatchet against us, and instigated to deluge our settlements with the blood of defenceless women and children.' Setting saide all question of the responsibility of the continentsil congress for acts of the Massechusetts provincial congress, and patting out of the discussion the suggestions that have been made as to the truth or falsity of General Gage's assertion that the rebels had first employed Indians, it must still be admitted that the vigorous language used by the continental congress in the declaration of independence and in the address to the people of Ireland was inconsistent with the position which they hsd already taken in the premises, and was calculated to deceive those who were ignorant what that position was.

I have said that the familiarity of Americans with the employment of Indians in previous wars, and the belief that the natives must be drawn into the contest anless we could secure Canads, probably caused our own people to look rather at the practical than the sentimental side of the question. With a complete knowledge of the ferocity manifested by Indians in their warfare, to which Americans alone would be exposed if Indians participated in the Far, there was at the aame time so general a belief in the probability of their being made use of on the one side or the other, that the efforts of the Mrasschnsetts provincial congress and of the English leaders to gain them over were probably looked apon by those who knew what was going on as perfectly nstural. This is partly inference and partiy deduced from the scts of Allen and 
Bayley and Arnold. Washington's letters show how he felt upon the subject. From the 'Familiar Letters' of John ddams we learn that Adams was present at a state dinner given by Washington at Cambridge, at which the Caghnawaga chiefs and their squars were among the guests. ${ }^{24}$ The view that John Adams took of the subject is to be found in a letter to Gates. 'We need not be so delicate,' he said, 'as to refuse the assistance of Indians, provided we cannot keep them neutral.' General Warren, in a letter to Samuel Adams, dated 14 May 1775, said: 'It has been suggested to me that an application from your congress to the Six Nations, accompanied with some presents, might have a very good effect.' The correspondence of prominent men of the period furnishes bat scant gleanings from which to determine the opinions of the writers, bat the newspapers of the time contain extracts from letters which illustrate the hopes, and at the same time indicate to some extent popular opinion, on the subject. From Worcester, on $10 \mathrm{Mray} 1775$, we have a rumour that the Senecas, one of the Sir Nations, are determined to support the colonies. From Pittsfield, $18 \mathrm{May}$, we learn that ' the Mowhawks had given permission to the Stockbridge Indians to join us, and also had five hundred men of their own in readiness to assist.' From all sides there were statements that Carleton was onsuccessful in his attempts to persuade the Canadian Indians to join his troops. In August it was stated that 'the Indian nations for a thousand miles westward are very stannch friends of the colonies.' In December the Boston Gazette asserted that 'last week his excellency the commander-in-chief received some despatches from the honourable continental congress by which we have authentic intelligence that several nations of the western Indians have offered to send three thousand men to join the American forces whenever wanted.' The very improbability of some of these rumours betrays that they sprang ont of the hopes of the people. Their publication without disepproring comment showg that if they had proved irue the colonists would not have been shocked.

For the more complete onderstanding of the subject a few words are required concerning the position of British officers who came in contact with the question. Lord Dunmore stood ready in May 1775 to raise the slaves in Virginis and to stir up the Indians. He was not only willing to take the initiative in the matter, offering no apology for it, but in the surnmer he sent an agent to General Gage to secure the necessary powers for doing so. Guy Johnson csserted that his own proceedings in the valley of the MFohawk

26 Familiar Letters, New Yot, 1876, p. 131 : 'I dined at colonel Mifflin's with the general and ledy and a vast collection of other company, among whom were six or seven sechems and warriors of the French C2ghnaway Indians vith sereral of their wives and children.' 
were predicated apon secret instructions received from General Gage. What those instructions were we have no means of discovering. The first trace, after the outbreak, of Gage's opinions is to be fond in the letter of 12 June, from which I have already quoted the clause referring to the Indians in the American camp at Cambridge. Bancroft, however, quotes from a letter to Carleton written in the fall of 1774, in which Gage asks Carleton's opinion as to ' whst messures would be most efficacions to raise a body of Cansdians and Indians, and for them to form a junction with the king's forces in this province.' It is probsbly doing Gage no injustice to sey that he took the military view of the matter, and was ready to act whenever opportunity occurred. The earl of Dartmouth told Johnson on 5 July 1775 ' to keep the Indians in such a state of affection and attachment to the king, that his majesty may rely upon their assistance in any case in which it may be necessary.' 25 On the 24th of the same month Dartmouth again wrote: "The intelligence his majesty has received of the rebels having excited the Indians to take a part, and of their having actually engaged a body of them in arms to support their rebellion, justifies the resolution his majesty has taken of requiring the asgistance of his faithful adherents the Six Nations. It is therefore his majesty's pleasure that you do lose no time in taking such steps as may induce them to take up the hatchet against his majesty's rebellious subjects in America, and to engage them in his majesty's service, upon such plan as shall be suggested by General Gage.' 20 It is not probable that any orders were issued from London for the employment of Indians prior to the reception of Gage's letter saying that it would be justifiable; and even if we accept the theory that the orders given to Johnson were positive to raise the Indians, that order could not have antedated the acts of the provincisl congress of Massachusetts Bay. In the sonthern department Staart asserted with apparent truth, as late as $18 \mathrm{Jvly}$, that he had never received any orders from his superiors "which by the most tortured suspicion could be interpreted to stir up or employ the Indians to fall upon the frontier inhsbitants, or to take any part in the dispate between Grest Britsin and the colonies.' Shortly after this date he received the orders from Gage which formed the basis of the correspondence that fell into Washington's hands, and furnished the general with the proofs to which he alluded in his letter to Schuyler.

In view of these facts, it may be doubted whether Gage's orders to Jabnson in May went to the length of anthorising Johnson to raise Indians for purposes of general warfare. Johnson reported that at Oswego the 'Indians agreed to defend the communications and assist his majesty's troops in their operations.' From

- Noe York Colonial Dacumenter vii. 592. Ib. 596 . 
the same place he prote to the New York provincial congress, protesting against the charges brought against him. 'I trust,' he said, - I shall always manifest more homanity than to promote the destruction of the innocent inhabitants of a colony to which I have always been warmly attached.' This language in the letter to the provincial congress is inconsistent with any open agreement with the Indians at that time to take ap arms against the colonies, but is entirely in harmony with the statements made by the friendly Indians at the conference at Albany that the superintendent's advice to them at Oswego was to preserve neutrality. At the Montreal conference ' the services of the Indians were secured for the king.' Here there was probably a direct agreement to take up arms. At Oswego there were present Indians who were known to be friendly to the Americans. At Montreal the Oneidas were not present, and the conference was held in a colony where rebellion had not raised its head. Johnson's conduct and his letter can to a certain extent be reconciled by the theory that his efforts with the Six Nations were exclusively directed towards securing from those Indians pledges to protect the carrying places from American occu. pation, and that the conference in Montreal was for the purpose of gaining the Indians to defend the province of Cansda from invasion. If this were true he might, by special pleading, defend the language of his letter, and say that he had not raised the Indians against his neighbours. He must hsve known, however, that self-protection demanded that Fort Stanwix should be held by the Americans, and that any attempt on the part of the Indians to prevent it would inevitably bring them in hostile contact with his ald neighbours. That be acted in this disingenuous manner appears probsble from the fact that the friendly Indians, who at the conference at Albany reported that he advised neutrality, themselves insisted with the American commissioners that their communications should not be disturbed. So far as the Montreal conference was concerned, Brant, the Mohawk chieftain, stated that, from the date of its meeting, the Indians who were present did all that they could for the king. With regard to this date for the alliance of the Six Nations, which was fixed by Brant from memory in an after statement of affairs, if it is to be relied apon, it militates against the theory that the result of the Montreal conference was to secure the Canadian Indians for defensive parposes alone.

It must be remembered, however, that Brant was thoroughly loyal to the king, and would nsiurally soek to make as much out of the services of the Indians as possible. This well-known chieftain had received an education at the Rev. Dr. Wheelock's school. He had been in London, and had been received by the king. By an adroit stroke of policy the superintendent appointed him as his private secretary, and thereby secured his powerful inflaence with 
the Mohawks. He was intelligent; and statements of this sort from his lips are to be weighed as coming from a man of fair standing.

The efforts pat forth by the American commissioners of the northern department in the fall and early winter of 1775 were exclusively in behalf of peace. To offset the power and influence of Guy Jobnson and Brant, they could only bring the inflaence of the missionaries. In the early part of the summer, Johnson had already done what he could to weaken Kirkland's hold upon the affection of the Oneidss. Notwithstanding the powerful combination of circumstances against the commissioners, they were able to divide the Sis Nations, and to hold a portion of the Oneidas and a few Tuscaroras to friendly relations with the colonists. The influence of these friendly Indians was powerful enough to secure the surrender of the war belt given by Gay Johnson at Montreal, and to restrain the hostile faction from outbreak for many months.

The Indians in the neighbourbood of Detroit appear to have drifted bodily over to the English.

It is not my purpose to follow the movements of the natives in connexion with the different campaigns of the war. The sanguinary affair at the Cedars, the outbreak of the Cherokees in 1776 in South Carolina, the battle of Oriskany, the movements of the Indians in company with Burgoyne, the massacres of Wyoming and of Cherry Valley, the marches and countermarches in the valley of the Ohio, the devastation of the Mohawk Valley, and the many minor raids all along the border, have been fally described by historians. Except so far as they show the overwhelming influence of the English among the Indians, and illustrate the cruelty of the natives when under the influence of transports of passion, they form no part of the subject which I have especially under consideration.

When in June 1776 the continental congress, hy the passage in quick succession of the severel resolutions anthorising the employment of Indians, showed that it had awakened to the necessity for action, the time was inopportune for securing the services of the natives. The force of the temporary success in Cansds was broken, and it was evident nothing bat disaster was in store for us in that quarter. About this time, however, some of the eastern Indians put in an appearance at Watertown. Washington had just transmitted to the provincial congress the resolation authorising the employment of the eastern Indians. The delegation was doly receired, and at the conference which was held with them they said : 'We shall have nothing to do with Old England, and all that we shall worship, or obey, will be Jesus Christ and George Washington.' These Indians cheerfully executed a treaty whereby they agreed to furnish 600 recroits to a regiment which was 
to be officered by whites and to have in addition to the Indians 250 white soldiers. Out of all this talk seven Penobscot Indisns were subsequently enlisted for one year, and a few from other tribes were secured for the continental service. The Indians of the eastern tribes repudiated the tresty, and said that the young men who made it had no authority for doing so. We hear of some of the Catawbas being with General Ratherford's command daring the invasion of the Cherokee territory in 1776. We find occasional mention in contemporaneous records of Indisns in connexion with the military movements of the Americans in the northern department. They were, however, so few in namber, that their services were of little value.

Whatever there was of real value to be derived from Indian suriliaries was gained by Great Britain. Whatever benefit there may be to the reputations of the king and of the ear] of Dartmouth in the fact that the provincial congress of Massachusetts Bay first employed Indians in military service in the Frar of the revolution, to that are they entitled. Whatever consolation may be drawn by Americsns from the fact that the continental congress moved slowly in the matter, and finally resolved with evident reluctance that it was expedient to employ Indians, will be freely conceded by any person who reads the record. That it would have been impossible to keep the Indians out of the fight, in the northern department, by any other method than the conquest of Canada, seems to be a just conclusion. That the true basis for criticism of the English for their acts in the premises is to be found, not in the priority of their employment of Indians, but in the despatch of expeditions in which the nambers of the natives so far preponderated that the officers in command conld not control them, will probably be the judgment of any dispassionate reader, who sets aside the heated contemporaneous accounts and reaches facts.

If we grant that the Americans anticipated the English in the employment of Indians as auriliaries; if we admit that they stand convicted, through extracts from their newspapers, of being hopeful that the natives might be secured upon our side; if we eoncede that the argument used by Suffolk when he justified the course of England was substantially the same as that used by Washington when speaking of the relations of America to the same subject, still a terrible responsibility rests apou the shoulders of the English leaders. They cannot plead ignorance of the dangers to which the inhsbitants of the frontiers of the colonies were exposed by the use of Indians apon military expeditions. The merciless denunciation by Chathsm, in 1777, of the ministry, even before the atrocities committed at Wyoming and at Cherry Valley had caused a thrill of horror to ran through the whole of Christendom, contained in its piled-up invectives a prophecy of what might 
be expected from engaging anriliary forces of such a character. In scathing language he charged the ministry with turning forth ' into our settlements, among our ancient connerions, friends, relations, the merciless cannibal, thirsting for the blood of man, womsn, and child ;' and of sending forth 'the infidel sarage-against whom? Agsinst your protestant brethren; to lay waste their country, to desolate their dwellings, and extirpate their race and name, with these horrible hell-hounds of savage war.' The dangers to be spprehended from the loss of control of the Indians when on the war path were folly understood.

Common feelings of humanity demanded that allies of such a charseter should only be used when sseocisted with bodies of disciplined troops, whose numbers should be so far superior to those of the Indians that control over their actions should never be in question. A violstion of this plain daty on the part of the English leaders led to the horrors of that terrible night in Wyoming Valley, when the naked prisonars were 'driven around a stake in the midst of a circle of flames,' while the sarages, mad with excitement, danced around them, greeting their piteous groans with yells of delight, and with thrusts of their spears prodded their victims on to still greater efforts in their hopeless struggle. 'It is not in my power to help it,' said the lesder of the expedition, and this was unfortunstely too true. The shocking details of the slanghter of women and children at Cherry Valley are chargesble to the doors of the English leaders on the same grounds. With a full knowledge of what was to be expected from such allies, the English employed them upon expeditions where the opportunity was afforded them of displaying in full force the most revolting features of their barbarous methods of warfare. The earl of Suffolk had justified the use of the nstives as anciliaries on the ground that the Americans first endearoured to raise them on the other side, and would have gained them if the English had not. If the Americans had succeeded, apon them would have rested the responsibility of so asing their allies thist history should not shrink from recording their deeds. America practically failed in her efforte. England succeded. The responsibility thus assumed by England was far greater than that which saccess would have imposed upon ber opponent. As allies of the American forces, the savages would have been able to vent their passions only on soldiers. Acting as auriliaries of the Engliah, the homes of bundreds of border settlers were exposed to their raids. It to prevent Americe from securing the military benefit of an Indian alliance that England employed the natives. By doing so she accepted responsibility for their acts, a responsibility which was neither increased nor diminished by the fact that America was willing to take the same responsibility on her shoulders. 